\title{
Verna M. Wulfekammer and the University of Missouri: Resources in the History of Art Education
}

\author{
Paula McNeil
}

In Women Art Educators, a 1982 publication sponsored by the Mary Rouse Memorial Fund at Indiana University and by the Women's Caucus of the National Art Education Association, editors Mary Ann Stankiewicz and Enid Zimmerman stressed the necessity for more historical research on women art educators and encouraged research, including oral history, about the contributions, status, and role of women in art education. They concluded that in order to accurately assess the future of women art educators, it is necessary to research their history as well as their present status. ${ }^{1}$

Addressing Stankiewicz and Zimmerman's appeal for more research on women art educators, in November 1988 I conducted an oral history with Verna M. Wulfekammer, art educator and artist at the University of Missouri from 1928-1968. (Figure 1) The real impetus behind this study was the creation of primary resource material relative to Wulfekammer's life and career as a teacher where none was available before.

In August 1989 the discovery and subsequent acquisition of the Verna M. Wulfekammer Collection in the Western Historical Manuscript Collection, the 1990 "recovery" of the Ella Victoria Dobbs/Verna M. Wulfekammer Library, and the Wulfekammer oral history created a rich cache of materials for the history of American art education scholarship at the University of Missouri.

\section{Oral History}

Prior to my first interview with Wulfekammer on November 20,1988, my initial research included combing the University of Missouri Archives as well as pertinent collections in the Western Historical Manuscript Collection in search of information pertinent to the history of the Education and Art Departments at the University of Missouri and to Wulfekammer's career as a teacher. I consulted a wide variety of materials, ranging from newspaper clippings, correspondence, photographs, maps, architectural drawings, to University catalogs, yearbooks, and schedules of classes. I also consulted standard histories of the University and read an overview of progressivism in American education. Although I turned up little information on Wulfekammer, I was, however, able to formulate interview questions from this research.

For my first interview, I used a tape recorder, $35 \mathrm{~mm}$ camera, note pad, campus map, photographs, and floor plans of various campus buildings. After the interviews the cassette tapes comprised primary resources with transcriptions which followed procedures for processing taped interviews 
outlined by the Northeast Archives of Folklore and Oral History at the University of Maine. ${ }^{2}$ The fieldwork data sheet and tape log followed the format specified by the American Folklife Center in Washington, D.C. ${ }^{3}$ Sample transcriptions, data sheets, and tape logs have been appended.

From the interviews, I learned that Wulfekammer's long career as an art educator at the University of Missouri began in 1928 when she assisted Ella Victoria Dobbs (Figure 2) teaching in the Applied Arts Department, located in Lathrop Hall and continued until her retirement in $1968 .{ }^{4}$

In addition to Wulfekammer's work with Dobbs in Lathrop Hall, she conducted research in elementary art education under the supervision of $C_{5}$. A. Phillips in the University Elementary School, located south of Lathrop Hall. ${ }^{5}$ Organized by Junius L. Meriam in 1907, two years before Ella Victoria Dobbs came to teach at Missouri in 1909, the University Elementary School was modeled on John Dewey's Laboratory School at the University of Chicago. ${ }^{6}$

Dobbs, a pioneer in the field of applied arts, studied Swedish sloyd (manual training) and received a B.S. degree from Teachers College, Columbia University, where she became familiar with the experimental work of John Dewey, Frederick Bonser, and Arthur Dow. Dobbs taught at the University of Missouri from 1909 until her own retirement in 1936. Her greatest contribution to the field of art education was the integration of handwork with other subjects. ${ }^{7}$ Together Dobbs and Wulfekammer played a formative role in the development of the University's art education program in the early part of this century.

\section{Verna M. Wulfekammer Collection}

In August of 1989 the Western Historical Manuscript Collection acquired the papers as well as selected artifacts of both Wulfekammer and her mentor, Dobbs. Spanning a period of almost nine decades, the Wulfekammer collection is an invaluable resource for students and researchers in art, art education, and the history of women in education. This is the story of its acquisition.

The story behind the acquisition of the Wulfekammer collection began more than a year ago while I was engaged in historical research for the University of Missouri, Department of Art's "Faculty Artist..." exhibition. This exhibit included works by former members of the art faculty at the University from 1877 to the present and ran from August 28 to September 24, 1989. During the initial stages of my research, I became intrigued by art educator and weaver, Verna Mary Wulfekammer, and her four decades at the University of Missouri. As a result of this fascination, I interviewed her on several occasions in November of 1988, creating several hours of tape and numerous papers of transcriptions. It was during one of these interviews that she agreed to loan one of her weavings to the exhibition. During those soft-spoken interviews in her living room, I quickly discovered the tremendous impact 
Dobbs, Wulfekammer's former teacher and, later, her colleague had on her life. Although at this time I was primarily interested in Wulfekammer and her career since so few written documents existed, it was obvious to me that "Miss Dobbs," as Wulfekammer called her, still had a strong hold on her. Although Dobbs died in 1952, and had been dead for thirty-six years, "Miss

Wulfekammer," as I call her, brought Dobbs back to life through voice imitation and gesture. For example, after I showed her a photograph of the interior of the University Elementary School, she launched into a rendition of Dobbs darting into the school room, talking rapidly "off the cuff," then running out the door "like the dickens." 8

I had little contact with Wulfekammer until months later. In August, as the deadline for the exhibition drew near, for several days I tried to contact her by phone to schedule a time to pick up her weaving. In desperation, I drove to her home on Sunday afternoon, August 20th, and left her a note concerning the weaving. The next morning I received an alarming phone call from one of her relatives, responding to the note I left on the door. Sadly, her relative informed me that she had been declared "mentally incompetent" and had been placed in a care center in Columbia. $\mathrm{He}_{\text {s }}$ as guardian and consenvator of her estate, loaned her weaving to the exhibit. At the same time he informed me that he and his wife were preparing Wulfekammer's effects to be sold at public auction on Saturday, September 2, 1989. He also told me that the auctioneer was scheduled to arrive in less than an hour to evaluate the estate. At that moment, feeling some urgency, I quickly shifted hats from one of the organizers of the exhibit to one as manuscript specialist and doctoral student in art education. I asked Mr. --- if I could visit with him at the Wulfekammer home within the next 20 minutes. He consented to my request.

When I arrived I found an invaluable collection of resource materials for the history of art education. For the next two weeks prior to the auction, I and colleagues from Manuscripts assessed the scope, content, and historical significance of the collection item by item. As we were going through the enormous amount of materials, I had to make a case for the historical value of the items versus the monetary worth they would possibly bring at auction. To make a long story short, as you know, Western Historical Manuscripts acquired the collection.

The Verna M. Wulfekammer Collection ( 36 cube boxes and oversize) includes papers and artifacts related to the teaching careers of both Wulfekammer and Dobbs. When Dobbs died in 1952, Wulfekammer acquired her estate, including her teaching library as well as her papers and teaching models.

The collection contains only a small amount of correspondence. Sadly, "boxes" of carbon copies of letters were discarded some time in March by relatives going through Wulfekammer's effects. They were disposed of because they were copies, not originals, and could presumably be obtained elsewhere. Although I mourn the loss of the historical record in those boxes, it 
is unlikely that personal correspondence between Dobbs and Wulfekammer was ever created in the first place since they lived in the same town. I wonder if Dobbs' correspondence from others was among the pitched material and whether or not she made copies of her out-going letters. In terms of correspondence in the collection, there are a few cards, gift enclosures, poems, etc. between the two of them and that is all.

The collection contains Wulfekammer's elementary, high school, and University of Missouri mementos, transcripts, records, commencement programs, newspaper clippings about Wulfekammer, Art Education Room plans, diagrams, descriptions, specifications (c. 1960) teaching/lecture notes ( 2 folders), teaching notebooks and research projects by Wulfekammer. Most of these were done by Wulfekammer when she was Dobbs' student, for example, Bookbinding, Primary Handwork, Intermediate Handwork, Toymaking. There are also materials such as curriculum guides, notebooks, and papers written by Wulfekammer's students on basketry, color, pottery, toymaking, primary handwork, letters, art activities, and art craft. The commercial publications on art education include books, pamphlets, advertisements, catalogs, to name a few. The weaving section includes publications, weaving drafts and samples, reports and articles, teaching notes, and other teaching resources. The collection contains publications by both Wulfekammer and Dobbs. Artifacts include "sloyd" work created by Dobbs when she was a student at Throop Polytechnic Institute; weaving; fabric samples; dolls, made of celluloid, wood, paper, fabric, and paint; hand puppets made of plaster, fabric, and paint; doll house furniture; baskets, toys, papier mache figures; masks, ceramic plates, metal objects, bookbinding samples, wire sculpture, wood carvings, linoleum printing blocks and prints, a book press, drawings by Wulfekammer and by her students, and a wire sculpture moose.

Although there is a typed manuscript of Wulfekammer's 1961 tribute to her mentor, Ella Victoria Dobbs: a Portrait Biography, the Dobbs primary resource materials she consulted, and presumably inherited from Dobbs, were regrettably not among Wulfekammer's effects.

\section{Ella Victoria Dobbs/Verna M. Wulfekammer Library}

The fate of the Dobbs/Wulfekammer collection of books given to Ellis Library, was yet another story. Originally, it was boxed and earmarked for the Friends of the Library sale where it was to be broken up and sold piecemeal. At first the Department of Art's request that it be transferred to the Art Education Department from Ellis Library was denied by the interim director of the libraries. After much perseverance and the submission to the University provost of a petition, signed by more than one hundred U.S. and foreign art educators attending the 1989 Second Penn State Conference on the History of Art Education to save the Dobbs/Wulfekammer Library, the interim director of the libraries acquiesced and the library was finally transferred to the Art Education Department in winter, 1990.

Working Papers in Art Education 1989 - 1990 
As is readily apparent. both the Verna $\mathrm{M}$. Wulfekammer Collection and the Dobbs/Wulfekammer Library are rich resources for the study of the history of art education. Possibilities for research are varied and have not been fully explored.

One possibility for research use is biography. Using documents from the collection, such as Wulfekammer's University of Missouri transcript, her student notebooks, and University of Missouri catalogs, one can begin not only to look at her life as one of Ella Victoria Dobbs' students but also as an art education student in a midwestern university in the $1920 \mathrm{~s}$.

Wulfekammer first met Dobbs the second semester of the 1923-24 academic year when she enrolled in Dobbs' elementary "ArtCraft" class. Other classes she took from Dobbs include Primary Handwork, Intermediate Handwork, and Bookbinding. Wulfekammer did well as Dobbs' student, for her transcript indicated that she received "Excellent" in all of her courses.

In 1928 Wulfekammer was hired as an assistant instructor, aiding Dobbs in the Applied Arts Department. At that time, Wulfekammer was also pursuing graduate work. From 1929-1931 in a report entitled "Study of Activities in Art and Handwork of Grade 1" she conducted research in elementary art education in the University Elementary School, a laboratory school based on John Dewey's famous Laboratory School of the University of Chicago. In 1931 she received her Masters of Art degree in education with Dobbs as her advisor.

Dobbs and Wulfekammer were colleagues for eight years, from 1928 until Dobbs' retirement in 1936. After that time, Wulfekammer was the Department until her own retirement in 1968.

Another way to approach the material might be to ask the question: Did Wulfekammer remain devoted to Dobbs' ideas throughout her career or did she develop her own ideas after Dobbs retired in 1936? Yet another approach to the material might be to examine the relationship between Wulfekammer and Dobbs in light of mentor-protege models. This kind of an examination would provide an angle for exploring the origins and dynamics of their friendship and focus on their time together from 1923 until Dobbs' death in 1952.

\section{References}

Bartis, Peter. Folklife and Fieldwork: A Layman's Introduction to Field Techniques. Washington D.C.: American Folklife Center, fourth printing, 1983.

Columbia, Missouri. Joint Collection. Western Historical Manuscripts Collection/State Historical Society of Missouri Manuscripts: Accession 4921. Verna M. Wulfekammer Collection 
Box 1, Photograph of Verna Wulfekammer, ca. 1963

Box 2, "Study of Activities in Art and Handwork of Grade 1"

Box 10, Photograph of Ella Victoria Dobbs, n.d.

Collection 965. Junius L. Meriam papers. Scrapbook

Ives, Edward D. The Tape-Recorded Interview: A Manual for Field

Workers in Folklore and Oral History. Knoxville: The University of Tennessee Press, 1980.

Stankiewicz, Mary Ann, and Enid Zimmerman, eds. Women Art Educators. Bloomington, Indiana: Indiana University, April, 1982.

Wulfekammer, Verna M. Retired associate professor of art, University of Missouri, Columbia. Interview, 20 November 1988. 1961 .

Ella Victoria Dobbs: a Portrait Biography. Pi Lambda Theta, 


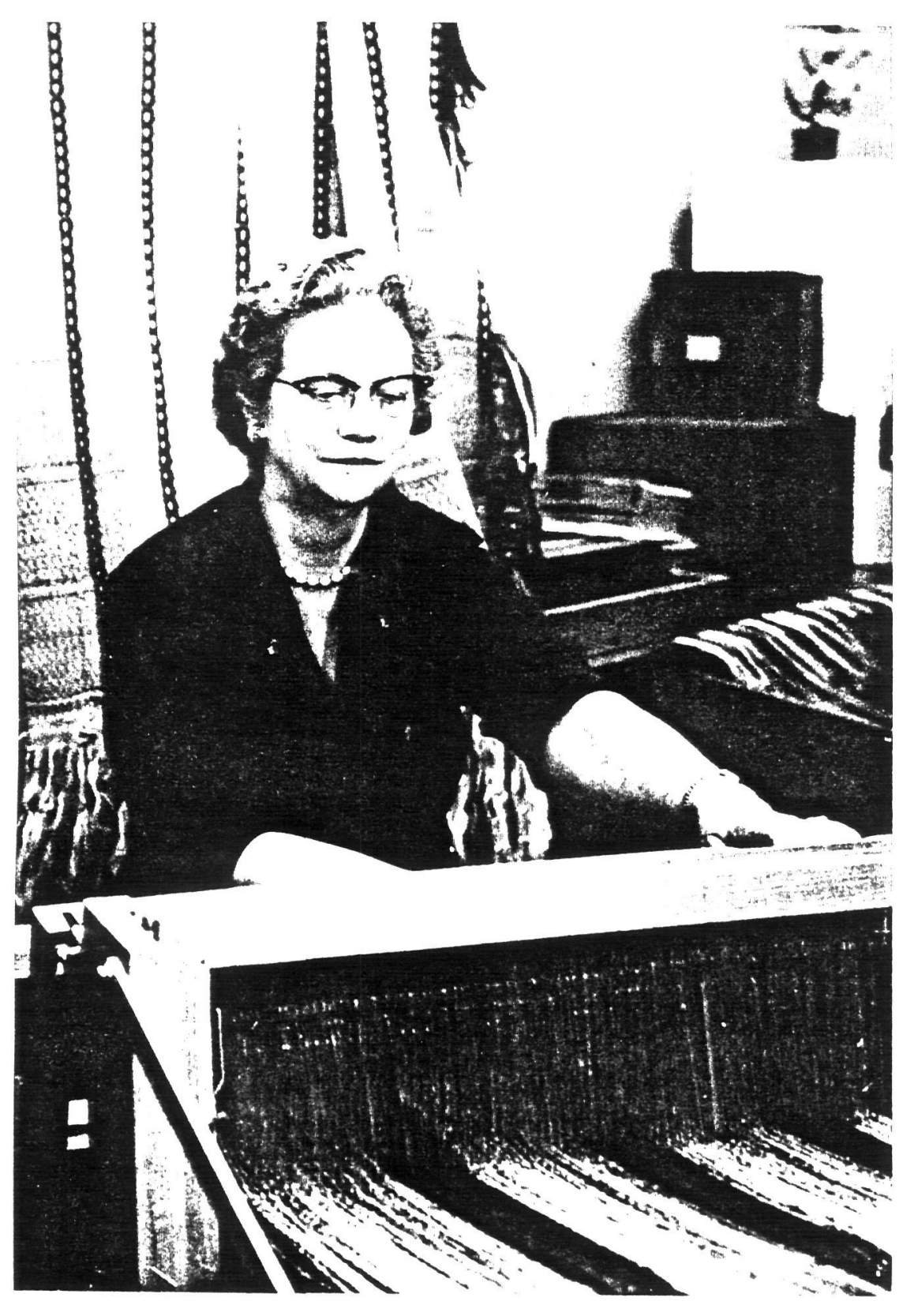

Figure 1. Verna M. Wulfekammer, ca. 1963. 


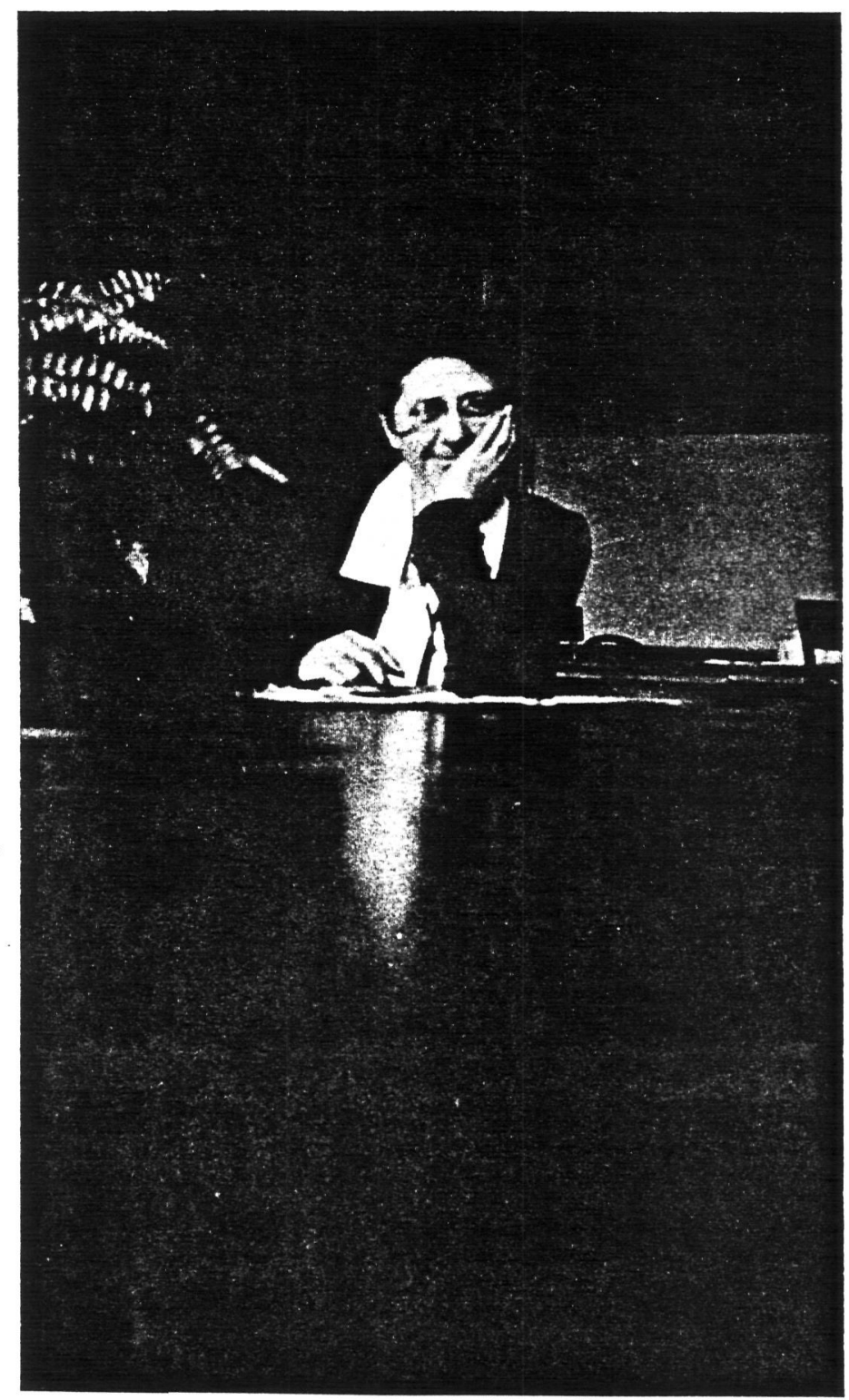

Figure 2. Ella Victoria Dobbs, n.d. 
Corresponding to tape No. 1

Collector: Paula L. McNeill

Circumstances of interview:

Oral history of Verna M. Wulfekammer, former University of Missouri-

Columbia, art education professor. Dates of employment: 1928-1968.

\section{INTERVIEW}

Date of interview: Sunday, November 20, 1988, 2:00-2:45 p.m.

Name: Verna M. Wulfekammer

Address: 810 Leawood Terrace, Columbia/443-0043

(She has resided at this address for approximately thirty years, since 1959.

Previous address: 6 Kuhlman Court, Columbia, from ca. 1923-1959.

Place and date of birth: Born May 13, 1900, on a farm near Levasy in Jackson County, Missouri, not far from the Bone Hill School.

Family information: Daughter of William $\mathrm{H}_{\text {. }}$ and Mary Olinda (Kronsaga)

Wulfekammer; had one older sister, Edna, born January 16, 1989. All

deceased.

Ethnic heritage (mother's and father's):

Mother: Kronsaga family from the Alsace/Lorraine area of France, near the German border.

Father: German. He was from Trealor, Missouri.

Education, apprenticeship and training experience:

Bone Hill School, a rural school near Levasy, Missouri

William Chrisman High School, Independence, Missouri

(valedictorian or salutatorian, 1920.)

B.S. University of Missouri, 1926.

M.A. University of Missouri, 1931

Post-graduate study, Columbia University, summer 1933. 1936.

U.C.L.A., Winter 1949

Occupational experience:

Elementary teacher, grades 1-8, Oldham School, a rural school south of Independence Missouri, 1920-1923

Elementary teacher, grade 4, Ott School, Independence, Missouri, 1926-1928 University of Missouri, Applied Arts Department (which later became the Art Education Department), 1928-1968 


\section{Tape Log}

Collector: Paula L. McNeill

Title: Oral history: Verna Mary Wulfekammer

Corresponding Data Sheet No. 1

Cassette tape

Interview date: Sunday, November 20, 1988

Time: 2:00-4:30 p.m. Length of interview: $21 / 2$ hours

Place of interview:

Home of Verna Wulfekammer

810 Leawood Terrace

Columbia, Missouri 65203

314/443-0043

Tape transcription:

PM = Paula McNeill

$\mathrm{VM}=$ Verna Wulfekammer

WW: After I left the University I came to get a piece of lumber and I went down to the Industrial Arts Department [located in present Academic Support Building] and a Mr. Selvidge [Robert Washington Selvidge] was the one who was there. Mr. Selvidge said to me: "You have come to the right place. Just go across the street [to Lathrop Hall]. Miss Dobbs [Ella Victoria Dobbs] is looking for a student, a helper, a laboratory assistant." And I was that the rest of the time.

PM: You have been very fortunate.

VM: I just walked into that. Mr. Selvidge said well you have just come to the right place. I know Miss Dobbs is looking for a laboratory assistant...I walked in [Lathrop Hall] and she gave me something to do... We had a whole row of boxes. Each student was given a box with tools like a ruler, a water pan, and a brush, and a box of crayons...maybe something else, I don't know...scissors, I believe. Anyway, each box had these tools in them. Each box was numbered and she said well I came just at the right time. She needed somebody to help her with her laboratory work. Miss Dobbs loved to talk. She could talk off the cuff, off the cuff. She could stand there and talk and talk and talk. I can't do that. She would come in and she would talk. Maybe not even have prepared what she was going to say... and I'd stay and listen. And then when she was through -- out she'd go like the dickens. Well, if this is the room where all the students were, then here is... [VM is sketching a floor plan of the Lathrop Hall classroom and Dobbs' office.]

Working Papers in Art Education 1989 - 1990 


\section{Notes}

1. Mary Ann Stankiewicz and Enid Zimmerman, eds., Women Art

Educators, (Bloomington, Indiana: Indiana University, April, 1982), 1.

2. Edward D. Ives. The Tape-Recorded Interview: a Manual for Fieldworkers in Folklore and Oral History. (Knoxville: The University of Tennessee Press, 1980), 87-102.

3. Peter Bartis. Folklife and Fieldwork: A Layman's Introduction to Field Techniques. (Washington D.C.: American Folklife Center, 1983), 18-21.

4. Verna M. Wulfekammer. Interview, 20 November 1988.

5. Verna M. Wulfekammer Collection. Western Historical Manuscript Collection-Columbia. Box 1.

6. Junius L. Meriam Papers. Collection 965. Scrapbook. Western Historical Manuscript Collection-Columbia.

7. Verna M. Wulfekammer. Ella Victoria Dobbs: a Portrait Biography (Pi Lambda Theta, 1961), 51.

8. Verna M. Wulfekammer. Interview, 20 November 1988. 